\title{
Biogeographical Conditions, the Transition to Agriculture and Long-Run Growth
}

\author{
Michael Bleaney and Arcangelo Dimico* \\ University of Nottingham
}

\begin{abstract}
We use new data on the timing of the transition to agriculture, developed by Putterman and Trainor (2006), to test the theory of Diamond (1997) and Olsson and Hibbs (2005) that an earlier transition is reflected in higher incomes today. Our results confirm the theory, even after controlling for institutional quality and other geographical factors. The date of transition is correlated with prehistoric biogeography (the availability of wild grasses and large domesticable animal species). The factors conducive to high per capita incomes today are good institutions, an early transition to agriculture, access to the sea and a low incidence of fatal malaria. Geographical influences have been at work in all of these proximate determinants of per capita income.
\end{abstract}

JEL No.: O11

Keywords: agriculture, geography, growth, institutions

*Corresponding author: Arcangelo Dimico, School of Economics, University of Nottingham, University Park, Nottingham NG7 2RD, UK. E-mail:lexad5@nottingham.ac.uk; tel. +44 115951 5464; +441159514159 


\section{1) Introduction}

What explains why some countries are rich today and some poor? Research has established that the most important factor is the quality of a country's institutions (Acemoglu et al., 2001; Hall and Jones, 1999; Rodrik et al., 2004). Acemoglu et al. (2001) argue that better institutions evolved where Europeans chose to settle, which tended to be in areas where their mortality rate was lower. Using settlers' mortality as an instrument for institutional quality, they show that geography, as measured by latitude, has no independent effect on per capita incomes, once institutional quality is controlled for.

This view has been challenged by Sachs (2003) and Olsson and Hibbs (2005). Sachs shows that geographical factors remain significant if they are represented by an index of the risk of fatal malaria rather than by latitude. Rodrik et al. (2004) confirm this result, although in their view its significance is limited because malaria risk ceases to be statistically significant once a dummy for sub-Saharan Africa is included.

Our particular focus here is the contribution of Olsson and Hibbs (2005) [OH]. Inspired by the work of Diamond (1997), OH argue that countries endowed with favourable biogeography in prehistoric times, as indicated by a greater variety of domesticable large animals and wild grasses suitable for cultivation, made the transition to agriculture at an earlier date. An early transition gave these countries a lead in economic development that they have never entirely lost, contrary to the 
"reversal of fortune" argument of Acemoglu et al. (2002). ${ }^{1} \quad$ Although catching up with and overtaking other countries is possible, $\mathrm{OH}$ argue (p. 927) that "regions with a well-endowed natural environment, which consequently made the transitions to agriculture and industry comparatively early, should other things equal have higher per capita today than more poorly endowed regions where the transitions came later." They develop an index of biological conditions conducive to agriculture, and in the empirical section of their paper they show that this is strongly positively correlated with current per capita GDP and the date of transition to sedentary agriculture. ${ }^{2}$

A weak point in OH's empirical work is that their dating of the transition to agriculture, which is based on Diamond (1997), is very imprecise and estimated only down to the regional level, as we discuss further below. Recently much more detailed estimates of the timing of this transition have been provided by Putterman and Trainor (2006), and these estimates differ quite substantially from those used by $\mathrm{OH}$. This raises the question of whether this new evidence is consistent with the Diamond-Olsson-Hibbs thesis.

This is the focus of our paper. First, we test whether the strong correlation between prehistoric biogeographical conditions and transition dates holds when this different source of data on the agricultural revolution is used. Second, we test the second link in the argument, that current per capita income is correlated with the timing of the establishment of secondary agriculture $(\mathrm{OH}$ do not actually test this, but only the

\footnotetext{
${ }^{1}$ To be precise, Acemoglu et al. (2002) argue that the reversal of fortune applies only to ex-colonies and not to all countries. We return to this point later.

2 Their index of biological conditions is the first principal component of two variables: the number of wild grasses with a mean kernel weight exceeding $10 \mathrm{mg}$ known to exist in prehistory, and the number of domesticable mammal species weighing more than $45 \mathrm{~g}$ known to exist in prehistory.
} 
correlation between prehistoric biogeography and current income). Third, we incorporate institutional quality along the lines of previous work, and we show that the time elapsed since the agricultural transition is a significant determinant of current per capita income even after controlling for institutions and other geographical variables. Fourth, we show that adding prehistoric biogeographical conditions to the regression does not improve the fit, indicating that the date of the agricultural transition is not simply acting as a proxy for some omitted geographical variable. In short, our findings are favourable to the $\mathrm{OH}$ hypothesis. Finally, we consider whether the date of the agricultural transition is still positively correlated with current per capita income when the sample is confined to ex-colonies, which would be a direct refutation of Acemoglu et al.'s (2002) argument that poorer colonies have overtaken initially richer ones because of their more "European" institutions.

The paper is organized in the following way. In Section Two we discuss the new data on the transition to sedentary agriculture and test the correlation of transition dates with biogeographical conditions at the time. In Section Three we introduce the model and data that we use to test the relationship between the date of the agricultural transition and current per capita income. Because of possible endogeneity of some of the independent variables, in Section Four we describe our empirical strategy in some detail. Section Five shows the main empirical results, whose robustness is tested in Section Six. The paper ends with a short conclusion. 


\section{2) Transition to Agriculture and Biogeography}

The starting point of our paper is the availability of new data on the transition from a hunter-gatherer existence to sedentary agriculture. Putterman and Trainor (2006) have produced detailed estimates of the timing of the transition to sedentary agriculture in 163 countries, using as the criterion the point at which the calorific intake from domesticated plants and animals is estimated first to have exceeded $50 \%$. These estimates are a great improvement on those used by $\mathrm{OH}$, who ascribe the transition in 112 countries to one of only six dates, ranging from 9847 years ago (all of Europe) to 4960 years ago (all African countries). Moreover in the OH data "neoEuropean" countries (Australia, Canada, New Zealand and the USA) are rather arbitrarily ascribed the European transition date.

Table 1 shows some basic statistics relating to Putterman and Trainor's estimates. As is well known, the earliest transition took place in the Middle East, on average almost 9000 years ago. African and Latin American countries experienced the most recent transition, almost 3000 years ago. The average West European and Asian country made the transition almost 5,500 years ago. 
Table 1: Descriptive Statistics for the Transition to Agriculture

\begin{tabular}{lcccc}
\hline Continent & Mean & Std. Dev. & Min & Max \\
\hline Africa & 3001 & 1170 & 1000 & 7200 \\
Latin America & 3043 & 1078 & 800 & 4300 \\
Asia & 5600 & 1487 & 4000 & 9000 \\
Eastern Europe & 6500 & 1282 & 3700 & 8000 \\
Western + New Europe & 5450 & 2389 & 400 & 10000 \\
Middle East & 8820 & 1303 & 7500 & 10500 \\
\hline
\end{tabular}

Notes: years before the present (source: Putterman and Trainor, 2006). New Europe is Australia, Canada, New Zealand and USA.

Table 2 compares the transition dates estimated by $\mathrm{OH}$ and Putterman and Trainor (2006) [PT]. Descriptive statistics for the $\mathrm{OH}$ measure of prehistoric biogeographical conditions are also shown. The mean year of the transition according to PT was 4800 years ago (4336 years ago for the countries covered by $\mathrm{HO})$, compared to 7420 according to $\mathrm{OH}$. The standard deviation are respectively 2440 and 2208.

Table 2: Descriptive Statistics for Transition Dates

\begin{tabular}{llllll}
\hline Variable & Countries & Mean & Std. Dev. & Min & Max \\
\hline & & & & & \\
Agricultural Transition (PT) & 163 & 4808 & 2440 & 362 & 10500 \\
$\begin{array}{l}\text { Agricultural Transition } \\
\text { (PT estimates; OH sample) }\end{array}$ & 108 & 4335 & 2325 & 362 & 10500 \\
Agricultural Transition (OH) & 112 & 7420 & 2208 & 4959 & 9846 \\
Prehistoric biogeography (OH) & 112 & 47.48 & 39.65 & 12.35 & 100
\end{tabular}

Notes: Agricultural transition is the years elapsed since the estimated date of transition; prehistoric biogeography is a measure of the number of species of domesticable large animals and wild plants. PT - Putterman and Trainor (2006); OH - Olsson and Hibbs (2005). 


\begin{tabular}{llll}
\hline & $\ln$ Agric (PT) & ln Agric (HO) & ln Biogeography \\
\hline & & & \\
ln Agricultural T. (PT) & 1 & & \\
ln Agricultural T. (Hibbs-Olsson) & 0.5767 & 1 & 1 \\
ln Biogeography (Hibbs-Olsson) & 0.5468 & 0.9666 & \\
& & & \\
\hline
\end{tabular}

Table 3 shows the pairwise correlation between biogeography and the date of the transition to agriculture. The correlation between the $\mathrm{OH}$ and PT transition dates is only 0.58 , which reflects the much more detailed character of PT's estimates. The correlation between the transition date and the index of biogeography is extremely high for the $\mathrm{OH}$ data, at 0.97 , and rather lower for the PT data (0.55), but this is still highly significant $(t=6.66)$. Thus the first stage of the $\mathrm{OH}$ hypothesis, that the agricultural transition was favoured by the availability of domesticable large animals and cultivable wild plant species, is still supported by the PT transition data.

\section{3) Data and Model}

The hypothesis which we wish to test in this paper is whether an earlier transition to agriculture has caused a lasting advantage in per capita income, once controls for the other deep determinants of the current level of development - the quality of institutions, geographical factors, and trade integration - are entered in the model. To put it another way, does the inclusion of the timing of the agricultural transition enable us to improve on the models estimated by Rodrik et al. (2004), who conduct rigorous econometric tests of the competing hypotheses? 
The model which we estimate for a cross-country sample can be written as:

$$
\log (y)=\alpha+\beta_{1} A T+\beta_{2} G E O+\beta_{3} Q I+\beta_{4} T R+v
$$

where $A T$ represents the timing of the transition to sedentary agriculture, GEO represents one or more geographical factors, $Q I$ is a measure of the quality of institutions, $T R$ represents openness to international trade, and $y$ is income per capita on a purchasing power parity basis for the year 2000, estimates for which come from the World Bank's World Development Indicators. Equation (1) is similar in form to that estimated by Rodrik et al. (2004), but with the addition of the agricultural transition variable.

The variable $A T$ is our measure of how long ago the transition to agriculture was estimated to occur, so a higher value represents an earlier transition. More precisely the variable is equal to the logarithm of the cumulative number of years before 2000 C.E. (A.D.) at which countries are supposed to have made the transition, as estimated by Putterman and Trainor (2006).

Geographical variables that have been used in cross-country growth analysis include a dummy for access to the sea, the proportion of a country that lies within the tropics, exposure to the risk of fatal malaria, latitude and European settlers' mortality (introduced by Acemoglu et al., 2001). Geographical variables have a dual function in equations like (1), because at least one of them is invariably used as an instrument 
for institutional quality. Acemoglu et al. (2001) and Rodrik et al. (2004) use settlers' mortality for this purpose. We replace settlers' mortality with latitude, since tests show that it is a superior instrument, ${ }^{3}$ and this also avoids truncation of the sample through lack of settlers' mortality data for some countries. The geographical variables included in the regression are the risk of fatal malaria (the contribution of regionally dominant vector mosquitoes to the potential transmission intensity of malaria) as used by Sachs (2003) and a measure of access to the sea (the ratio of a country's continental shelf area $^{4}$ to its surface area), which is similar to a dummy for sea access but allows for more variation across countries. Data on the continental shelf area are provided by Pruett and Cimino (2000) and published by the UNEP.

To proxy institutions we use two alternative indices. The first one is an index of property rights protection from Gwartney and Lawson (2006), as published by the Fraser Institute. The second measure, which is available for considerably more countries, is an index of the rule of law ${ }^{5}$ supplied by Kaufmann et al. (2005) and published by the World Bank. Finally, trade as a ratio of GDP at current prices is used as a measure of the openness of the country. Data are collected from Heston and Summers (2006) (PWT 6.2).

\footnotetext{
${ }^{3}$ Settlers' mortality tends to fail the Stock-Yogo test for weak instruments, implying that it is insufficiently correlated with institutional quality.

4 The shelf area is defined as "the extended perimeter of each continent and associated coastal plain, which is covered during interglacial periods such as the current epoch by relatively shallow seas (known as shelf seas) and gulfs. The shelf usually ends at a point of increasing slope (called the shelf break). The sea floor below the break is the continental slope. broad, relatively shallow submarine platform that forms a border to a continent"(Wikipedia).

5 "Rule of law combines several indicators that measure the extent to which agents have confidence in and abide by the rules of society. These include perceptions of the incidence of both violent and non-violent crime, the effectiveness and predictability of the judiciary, and the enforceability of contracts" (Kaufmann et al., 2005).
} 


\section{3) Empirical Strategy}

Although in equation (1) geographical factors and the elapsed time since the transition to agriculture can reasonably be considered exogenous to current per capita income, the same cannot be said for institutions and trade integration. The problem is to find plausible instruments for these variables. Like Rodrik et al. (2004), we use the predicted trade shares estimated by Frankel and Romer (1999) [FR] as an instrument for openness to international trade. As already mentioned, we use latitude as an instrument for institutional quality.

Table 4: Pairwise Correlation Matrix

\begin{tabular}{|c|c|c|c|c|c|c|c|c|c|c|c|}
\hline & Open & Law & P. Rights & Agric. T & $\begin{array}{l}\text { Shelf } \\
\text { A. }\end{array}$ & Latit. & $\begin{array}{l}\text { F.\&R. } \\
\text { Trade }\end{array}$ & Temper & Frost & Eurofrac & Wet \\
\hline Openness & 1.0000 & & & & & & & & & & \\
\hline Rule of Law & 0.2791 & 1.0000 & & & & & & & & & \\
\hline Prop. Rights & 0.2787 & 0.8919 & 1.0000 & & & & & & & & \\
\hline Agric. Transit. & 0.0856 & 0.0286 & 0.1141 & 1.0000 & & & & & & & \\
\hline Shelf Area & 0.1664 & -0.0344 & 0.1328 & -0.0781 & 1.0000 & & & & & & \\
\hline Latitude & 0.0991 & 0.5025 & 0.6611 & 0.3951 & -0.1326 & 1.0000 & & & & & \\
\hline F.\& R. Trade & 0.5625 & 0.1741 & 0.1770 & 0.0650 & 0.1921 & -0.0318 & 1.0000 & & & & \\
\hline Temperature & -0.0672 & -0.3737 & -0.5415 & -0.3185 & 0.1223 & -0.8651 & 0.1714 & 1.0000 & & & \\
\hline Frost Days & 0.0480 & 0.3042 & 0.4949 & 0.3115 & -0.0929 & 0.8140 & -0.1859 & -0.9526 & 1.0000 & & \\
\hline Euro-Fraction & -0.0246 & 0.3437 & 0.1610 & -0.3337 & -0.0463 & -0.0369 & -0.0085 & 0.0415 & -0.0759 & 1.0000 & \\
\hline Wet Days & 0.2613 & 0.1988 & 0.0748 & -0.1303 & 0.0753 & -0.0121 & 0.1223 & -0.1491 & 0.1188 & 0.3080 & 1.0000 \\
\hline
\end{tabular}

In Table 4 we show the pairwise correlation between presumed endogenous variables and some of the possible instruments. Latitude has a stronger correlation with property rights and rule of law than any other variable. Measures of the share of 
population speaking English or other European languages (introduced by Hall and Jones, 1999, and used by Rodrik et al., 2004, in some regressions) do not have a particularly large correlation with institutions. The FR predicted trade share is significantly correlated with trade openness. Consequently we use latitude as the main instrument for institutions and the FR predicted trade share as an instrument for integration. We show below that these variables pass the Stock-Yogo (2005) test for weak instruments. In the first-stage regressions, measures of institutions and trade integration are regressed on all the exogenous variables, and as a consequence our first stage regressions can be written as:

$$
\begin{gathered}
\text { INST }_{\mathrm{i}}=\theta_{\mathrm{i}}+\delta_{1} \text { Agric }_{\cdot \mathrm{i}}+\delta_{2} \mathrm{Geo}_{\mathrm{i}}+\delta_{3} \text { FR. Trade }_{\mathrm{i}}+\delta_{4} \text { Latitude }_{. \mathrm{i}}+\mu_{\mathrm{i}} \\
\text { OPEN }_{\mathrm{i}}=\eta_{\mathrm{i}}+\lambda_{1} \text { Agric }_{. \mathrm{i}}+\lambda_{2} \text { Geo }_{\mathrm{i}}+\lambda_{3} \text { FR. Trade }_{\mathrm{i}}+\lambda_{4} \text { Latitude }_{. \mathrm{i}}+\varepsilon_{\mathrm{i}}
\end{gathered}
$$

\section{4) Results}

Table 5 reports ordinary least squares (OLS) results for equation (1), using property rights (Model 1) and the rule of law (Model 2) as the measure of institutional quality. The sample size is considerably larger when rule of law is used, but the results are fairly similar. Institutional quality is easily the most significant variable, particularly in Model 2. An earlier transition to agriculture (AT) is associated with a higher current per capita income, and the effect is significant at the 0.01 level. In Models 3 and 4 we add fatal malaria risk as an explanatory variable. This index (originally 
called malaria ecology) was developed by Kizsewski et al. (2004) and measures "the contribution of regionally dominant vector mosquitoes to the potential transmission intensity of malaria". It is not simply a measure of the probability of dying for malaria (which is likely to be affected by the quality of medical and other public services and therefore by per capita income), but attempts to capture the exogenous environmental component of this (Sachs, 2003, uses it as an instrument for malaria fatalities). Fatal malaria risk is highly (negatively) significant, and its inclusion reduces the estimated magnitude of the AT effect, although AT is still significant at the 0.05 level.

However, because OLS is not consistent in the presence of endogenous variables, we run the augmented Durbin-Wu-Hausman test to check whether institutions and trade are truly endogenous, using latitude and FR trade shares as the potential instruments. In this test, residuals from the first stage of two-stage least squares (2SLS) estimation are added to the OLS equations shown in Table 5, and the null of exogeneity is rejected if the fit significantly improves. The results suggest that there is a problem of endogenous regressors in all models except Model 4.

Accordingly in Table 6, we show the 2SLS estimates of the same equations, treating both institutions and openness as endogenous. Panel A of Table 6 shows the secondstage results, and Panel B shows the first-stage regressions for each endogenous variable, which indicate that latitude and FR trade shares are very strong instruments for institutional quality and trade openness respectively. 
Table 5: OLS Estimates for the Income Level Model

\begin{tabular}{|c|c|c|c|c|}
\hline \multicolumn{5}{|c|}{ Dependent Variable: In per capita Income (2000) PPP adjusted } \\
\hline \multirow{2}{*}{ ESTIMATION METHOD: OLS } & \multicolumn{4}{|c|}{ COEFFICIENTS } \\
\hline & Model 1 & Model 2 & Model 3 & Model 4 \\
\hline \multirow[t]{2}{*}{ Institutional Quality (Property Rights) } & $0.463 * * *$ & & $0.382 * * *$ & \\
\hline & $(14.95)$ & & $(13.00)$ & \\
\hline \multirow[t]{2}{*}{ Institutional Quality (Rule of Law) } & & $0.978 * * *$ & & $0.881 * * *$ \\
\hline & & (22.98) & & (20.86) \\
\hline \multirow[t]{2}{*}{ Log Agricultural Transition Date } & $0.295 * * *$ & $0.245 * * *$ & $0.190 * *$ & $0.154 * *$ \\
\hline & $(3.47)$ & $(3.83)$ & $(2.10)$ & $(2.37)$ \\
\hline \multirow[t]{2}{*}{ Shelf area/Surface Area } & $0.0357 * *$ & $0.0369 * * *$ & $0.0568 * *$ & $0.0494 * * *$ \\
\hline & $(2.03)$ & $(4.08)$ & $(2.41)$ & $(2.68)$ \\
\hline \multirow[t]{2}{*}{ Log Openness } & $0.222 *$ & 0.147 & $0.285^{* *}$ & 0.124 \\
\hline & $(1.78)$ & $(1.49)$ & $(2.42)$ & $(1.36)$ \\
\hline \multirow[t]{2}{*}{ Malaria Risk } & & & $-0.0619 * * *$ & $-0.0436 * * *$ \\
\hline & & & $(-8.44)$ & $(-7.03)$ \\
\hline \multirow[t]{2}{*}{ Constant } & $2.544 * * *$ & $5.782 * * *$ & $3.820 * * *$ & $6.793 * * *$ \\
\hline & $(2.72)$ & $(8.01)$ & $(4.20)$ & $(9.76)$ \\
\hline Endogeneity Test for Inst and Open. (p-values) & 0.0010 & 0.0338 & 0.0889 & 0.2369 \\
\hline Endogeneity Test for Institutions (p-values) & & & & 0.1795 \\
\hline Endogeneity Test for Openness (p-values) & & & & 0.2333 \\
\hline Observations & 110 & 145 & 108 & 142 \\
\hline Root MSE & 0.685 & 0.604 & 0.580 & 0.547 \\
\hline R-squared & 0.67 & 0.74 & 0.77 & 0.79 \\
\hline
\end{tabular}

1)Breusch-Pagan / Cook-Weisberg test for heteroscedasticity: $H_{0}=$ Constant variance (p-values): 0.0018 for Model 1; 0.0000 for Model 2; 0.1113 for Model 3; and 0.0010 for Model 4.

2) Robust t-statistics in parentheses; *significant at $10 \%$; **significant at $5 \%$; *** significant at $1 \%$

3) The endogeneity test is the Durbin-Wu-Hausman test of the significance of the first-stage residuals in the augmented OLS regression. 
Table 6: 2SLS Estimates

\begin{tabular}{|c|c|c|c|c|}
\hline \multicolumn{5}{|c|}{ Dependent Variable: $\ln 2000$ per capita income at PPP } \\
\hline Independent variables & Model 1 & Model 2 & Model 3 & Model 4 \\
\hline Institutional Quality (Property Rights) & $\begin{array}{l}0.573 * * * \\
(12.15)\end{array}$ & & $\begin{array}{l}0.443 * * * \\
(10.38)\end{array}$ & \\
\hline Institutional Quality (Rule of Law) & & $\begin{array}{l}1.172 * * * \\
(12.74)\end{array}$ & & $\begin{array}{l}0.973 * * * \\
(9.95)\end{array}$ \\
\hline Log Agricultural Transition Date & $\begin{array}{l}0.269 * * * \\
(3.17)\end{array}$ & $\begin{array}{l}0.171 * * \\
(2.48)\end{array}$ & $\begin{array}{l}0.187 * * \\
(2.12)\end{array}$ & $\begin{array}{l}0.134 * * \\
(2.01)\end{array}$ \\
\hline Shelf Area/Surface Area & $\begin{array}{l}0.0486 * * \\
(2.17)\end{array}$ & $\begin{array}{l}0.0492 * * * \\
(3.73)\end{array}$ & $\begin{array}{l}0.0639 * * \\
(2.20)\end{array}$ & $\begin{array}{l}0.0506^{* * *} \\
(2.22)\end{array}$ \\
\hline Log Openness & $\begin{array}{l}-0.160 \\
(-0.70)\end{array}$ & $\begin{array}{l}-0.230 \\
(-1.13)\end{array}$ & $\begin{array}{l}0.0082 \\
(0.04)\end{array}$ & $\begin{array}{l}-0.100 \\
(-0.56)\end{array}$ \\
\hline Fatal Malaria Risk & & & $\begin{array}{l}-0.0553 * * * \\
(-7.09)\end{array}$ & $\begin{array}{l}-0.0392 * * * \\
(-5.40)\end{array}$ \\
\hline Constant & $\begin{array}{l}3.743^{* * * *} \\
(3.33)\end{array}$ & $\begin{array}{l}7.959 * * * \\
(7.81)\end{array}$ & $\begin{array}{l}4.648 * * * \\
(4.42)\end{array}$ & $\begin{array}{l}7.885^{* * * *} \\
(8.51)\end{array}$ \\
\hline Observations & 100 & 120 & 98 & 117 \\
\hline Cragg-Donald F statistic & 25.94 & 41.77 & $(24.90)$ & $(25.60)$ \\
\hline Stock-Yogo Critical Values for CD Statistic & $(7.03)$ & $(7.03)$ & 7.03 & 7.03 \\
\hline Anderson canon. statistic ${ }^{2}$ & 43.58 & 37.88 & 42.39 & 44.38 \\
\hline Hansen $\mathbf{J}$ statistic & 0.0000 & 0.000 & 0.0000 & 0.000 \\
\hline Root MSE & 0.73 & 0.64 & 0.59 & 0.56 \\
\hline R-Squared & 0.62 & 0.72 & 0.75 & 0.79 \\
\hline
\end{tabular}

1) The Anderson canon. corr. LR statistic is a likelihood-ratio test of whether the equation is identified. Under the null the model is under-identified. Test not robust to heteroscedasticity.

2) The Hansen $\mathbf{J}$ statistic is a test of overidentifying restrictions. The joint null hypothesis is that the instruments are valid instruments, and that the excluded instruments are correctly excluded from the estimated equation.

3 ) The figures in parentheses are robust $t$-statistics; $* * *, * * *$ : significant at 10,5 , and $1 \%$ respectively

Panel B: Firs- Stage Regressions

\begin{tabular}{|c|c|c|c|c|c|c|c|c|}
\hline & Model 1 & Model 2 & Model 3 & Model 4 & Model 1 & Model 2 & Model 3 & Model 4 \\
\hline & $\begin{array}{l}\text { Property } \\
\text { Rights }\end{array}$ & $\begin{array}{l}\text { Rule of } \\
\text { Law }\end{array}$ & $\begin{array}{l}\text { Property } \\
\text { Rights }\end{array}$ & $\begin{array}{l}\text { Rule of } \\
\text { Law }\end{array}$ & \multicolumn{4}{|c|}{ Openness } \\
\hline Agricultural Transiton & $\begin{array}{l}-0593 * * * \\
(-2.71)\end{array}$ & $\begin{array}{l}-0.153 \\
(-1.29)\end{array}$ & $\begin{array}{l}-0.546^{* *} \\
(-2.01)\end{array}$ & $\begin{array}{l}-0.101 \\
(-0.72)\end{array}$ & $\begin{array}{l}-0.015 \\
(-0.27)\end{array}$ & $\begin{array}{l}-0.035 \\
(-0.68)\end{array}$ & $\begin{array}{l}-0.008 \\
(-0.12)\end{array}$ & $\begin{array}{l}-0.035 \\
(-0.59)\end{array}$ \\
\hline Continental Shelf area & $\begin{array}{l}0.035 \\
(1.60)\end{array}$ & $\begin{array}{l}0.031 * \\
(1.91)\end{array}$ & $\begin{array}{l}0.077 \\
(0.89)\end{array}$ & $\begin{array}{l}0.090^{*} \\
(1.75)\end{array}$ & $\begin{array}{l}0.038 * * * \\
(4.41)\end{array}$ & $\begin{array}{l}0.037 * * * \\
(4.21)\end{array}$ & $\begin{array}{l}0.0428 * \\
(1.86)\end{array}$ & $\begin{array}{l}0.038 * \\
(1.70)\end{array}$ \\
\hline FR . Trade Share & $\begin{array}{l}0.403 * * \\
(2.02)\end{array}$ & $\begin{array}{l}0.240 * * \\
(2.37)\end{array}$ & $\begin{array}{l}0.409 * * \\
(2.06)\end{array}$ & $\begin{array}{l}0.234 * * \\
(2.22)\end{array}$ & $\begin{array}{l}0.429 * * * \\
(7.57)\end{array}$ & $\begin{array}{l}0.431 * * * \\
(8.71)\end{array}$ & $\begin{array}{l}0.433 * * * \\
(7.47)\end{array}$ & $\begin{array}{l}0.440 * * * \\
(8.31)\end{array}$ \\
\hline Latitude & $\begin{array}{l}0.088 * * * \\
(9.55)\end{array}$ & $\begin{array}{l}0.043 * * * \\
(8.97)\end{array}$ & $\begin{array}{l}0.086 * * * \\
(8.44)\end{array}$ & $\begin{array}{l}0.040 * * * \\
(7.56)\end{array}$ & $\begin{array}{l}0.002 \\
(0.51)\end{array}$ & $\begin{array}{l}0.003 \\
(1.08)\end{array}$ & $\begin{array}{l}0.013 \\
(0.37)\end{array}$ & $\begin{array}{l}0.0016 \\
(0.48)\end{array}$ \\
\hline Malaria Risk & & & $\begin{array}{l}-0.0067 \\
(-0.43)\end{array}$ & $\begin{array}{l}-0.013 * \\
(-1.91)\end{array}$ & & & $\begin{array}{l}-0.0004 \\
(-0.06)\end{array}$ & $\begin{array}{l}-0.0062 \\
(-1.02)\end{array}$ \\
\hline Constant & $\begin{array}{l}7.359 * * * \\
(3.96)\end{array}$ & $\begin{array}{l}-0.430 \\
(-0.42)\end{array}$ & $\begin{array}{l}7.016 * * * \\
(3.03)\end{array}$ & $\begin{array}{l}-0.716 \\
(-0.59)\end{array}$ & $\begin{array}{l}3.076 * * * \\
(7.30)\end{array}$ & $\begin{array}{l}3.214 * * * \\
(7.83)\end{array}$ & $\begin{array}{l}3.017 * * * \\
(5.82)\end{array}$ & $\begin{array}{l}3.251 * * * \\
(6.66)\end{array}$ \\
\hline Partial R-squared & 0.54 & 0.50 & 0.47 & 0.41 & 0.35 & 0.36 & 0.35 & 0.36 \\
\hline Shea Partial R-squared & 0.54 & 0.46 & 0.47 & 0.38 & 0.36 & 0.33 & 0.35 & 0.33 \\
\hline
\end{tabular}

The figures in parentheses are robust $t$-statistics; *,**,***: significant at 10,5 , and $1 \%$ respectively 
Various test statistics indicate the adequacy of the instruments in Table 6. The Anderson statistic rejects the hypothesis of under-identification, while the Hansen Jstatistic indicates that the null of exact identification cannot be rejected. The CraggDonald F-statistic exceeds Stock and Yogo (2005) critical values for two endogenous variables, which confirms that instruments and endogenous variables are strongly correlated, providing consistent estimates in the second stage. The Shea partial Rsquareds are also similar to the standard partial R-squareds from the first-stage regressions, which indicates that the instrument vectors are relatively uncorrelated. ${ }^{6}$

Compared to OLS estimates, the proxy for trade integration is the only variable which completely loses significance in the 2SLS models, although it keeps its sign. Our proxy for the elapsed time since the transition to agriculture is significant at a $1 \%$ level in Model 1 and at 5\% in Models 2 to 4 . Its coefficient suggests that a transition to agriculture $10 \%$ earlier is associated with a per capita income between 1.3\% (Model 4) and 2.7\% (Model 1) higher today. Although this sounds quite a small effect, the dispersion of transition dates across countries is very wide.

The first-stage regressions (reported in Panel B) suggest a negative correlation between institutional quality and the transition to agriculture (significant for property rights but not rule of law). This negative correlation is consistent with Acemoglu et al's (2002) argument that the colonisation process resulted in a "reversal of fortune", with poorer and less populated regions absorbing more European settlers and therefore having more "European" institutions. We return to this point later.

\footnotetext{
${ }^{6}$ If they were highly correlated, they would effectively little better than one instrument, in which case the model would be underidentified (Shea, 1996).
} 


\section{5) Further Analysis}

The results in Tables 5 and 6 support the Diamond-OH hypothesis that an earlier transition to agriculture is associated with higher per capita incomes today. Since, as we have already seen, the timing of the transition to agriculture is correlated with prehistoric biogeography, this result may just reflect some omitted geographical influences. To test this, in Table 7 we add the $\mathrm{OH}$ prehistoric biogeography variable to the regression. If the true explanation for our previous results is an omitted geographical effect, it should outperform the agricultural transition variable.

In Models 1 and 2 of Table 7 we re-estimate Models 2 and 4 of Table 6 omitting the insignificant trade variable, which increases the number of observations, particularly in the case of the rule of law (to 143 instead of 120, and to 109 rather than 100 for property rights). The agricultural transition variable now has a slightly larger coefficient (and $t$-statistic) than in the equivalent regressions in Table 6. When we add prehistoric biogeography (Models 3 and 4 of Table 7), its coefficient is statistically insignificant and negative. Thus the second stage of the Diamond-OH hypothesis appears to be confirmed. 
Table 7: Adding Prehistoric Biogeography

\begin{tabular}{|c|c|c|c|c|}
\hline \multicolumn{5}{|c|}{ Dependent Variable: $\ln 2000$ per capita GDP (PPP) } \\
\hline ESTIMATION METHOD: 2 SLS & Model 1 & Model 2 & Model 3 & Model 4 \\
\hline Institutional Quality (Property Rights) & $\begin{array}{l}0.450 * * * \\
(9.82)\end{array}$ & & $\begin{array}{l}0.509 * * * \\
(5.09)\end{array}$ & \\
\hline Institutional Quality (Rule of Law) & & $\begin{array}{l}1.032 * * * \\
(8.66)\end{array}$ & & $\begin{array}{l}1.092 * * * \\
(5.10)\end{array}$ \\
\hline Log Agricultural Transition Date & $\begin{array}{l}0.208 * * \\
(2.43)\end{array}$ & $\begin{array}{l}0.152 * * \\
(2.31)\end{array}$ & $\begin{array}{l}0.305^{* *} \\
(2.25)\end{array}$ & $\begin{array}{l}0.240 * \\
(1.87)\end{array}$ \\
\hline Shelf Area / Surface Area & $\begin{array}{l}0.0654 * * * \\
(2.84)\end{array}$ & $\begin{array}{l}0.0337 \\
(1.48)\end{array}$ & $\begin{array}{l}0.0691 * * * \\
(2.84)\end{array}$ & $\begin{array}{l}0.0494 * * \\
(2.16)\end{array}$ \\
\hline Fatal Malaria Risk & $\begin{array}{l}-0.0551 * * * \\
(-6.84)\end{array}$ & $\begin{array}{l}-0.0375 * * * \\
(-4.95)\end{array}$ & $\begin{array}{l}-0.0582 * * * \\
(-6.65)\end{array}$ & $\begin{array}{l}-0.0386^{* * *} \\
(-5.00)\end{array}$ \\
\hline Log Prehistoric Biogeography & & & $\begin{array}{l}-0.159 \\
(-0.79)\end{array}$ & $\begin{array}{l}-0.131 \\
(-0.66)\end{array}$ \\
\hline Constant & $\begin{array}{l}4.476^{* * * *} \\
(5.65)\end{array}$ & $\begin{array}{l}7.332 * * * \\
(12.95)\end{array}$ & $\begin{array}{l}3.852 * * * \\
(3.58)\end{array}$ & $\begin{array}{l}6.976^{* * * *} \\
(11.21)\end{array}$ \\
\hline Cragg-Donald F statistic & 57.70 & 33.00 & $\begin{array}{l}17.14 \\
(7.03)\end{array}$ & 11.53 \\
\hline Anderson LR statistic & 48.11 & 30.66 & 16.71 & 11.57 \\
\hline Hansen J statistic & 0.0000 & 0.0000 & 0.0000 & 0.0000 \\
\hline Endogeneity test (p-values) & 0.2831 & 0.1909 & 0.4383 & 0.5121 \\
\hline Root MSE & 0.59 & 0.55 & 0.60 & 0.53 \\
\hline R-Squared & 0.75 & 0.78 & 0.76 & 0.82 \\
\hline Observations & 109 & 143 & 89 & 106 \\
\hline
\end{tabular}

1) See Notes to Table 6. Prehistoric Biogeography data are only available for 112 countries.

2) The figures in parentheses are robust $t$-statistics; *** $\mathrm{p}<0.01$, ** $\mathrm{p}<0.05$, * $\mathrm{p}<0.1$

We now perform some additional robustness checks. In Table 8 we use additional controls. First we include a dummy for oil producers. Many oil producers are located in the Middle East, the region with the earliest transition to agriculture, so it is possible that the positive effect of the transition to agriculture really captures the effect of oil producers. ${ }^{7}$ The International Energy Agency (IEA) is the source we use to build our dummy for oil producers.

\footnotetext{
${ }^{7}$ We use data from the International Energy Agency to identify oil producers.
} 
A second possibility is that AT is capturing the negative effect of ethnic diversity. Several authors, such as Easterly and Levine (1997), find a negative effect of ethnic diversity on growth, and African countries, which mostly had a late transition to agriculture, also tend to have high ethnic diversity. We use the ethno-linguistic fractionalization index of Fearon and Laitin (2003). In the model with the property rights (Model 2), the variable is significant at a $10 \%$ level, while the transition to agriculture is significant at a $5 \%$ level. The index of ethnic fractionalization is not significant in the model with the rule of law (Model 5). The transition to agriculture in this model is significant at a $10 \%$ level.

The third possibility that we entertain is that AT is just reflecting regional effects. To control for this we add dummy variables for Latin American and Africa countries.

Table 8 shows the results, first for property rights (Models 1 to 3 ), and then for the rule of law (Models 4 to 6). The dummy for oil producers has a significant positive coefficient, but the AT coefficient remains significantly positive (Models 1 and 4). Ethnic fractionalization is marginally significant for property rights and has a negative coefficient. The Latin America dummy is positive and significant, and the Africa dummy is negative and insignificant. With the regional dummies AT remains significant at the 0.05 level (Models 3 and 6). Only in Model 5 (ethnic fractionalizaton; rule of law) does AT cease to be significant at the 0.05 level, and ethnic fractionalization is highly insignificant in this regression, which suggests that this is the result of multicollinearity. 
Table 8: Robustness Checks

\begin{tabular}{|c|c|c|c|c|c|c|}
\hline \multicolumn{7}{|c|}{ Dependent Variable: In 2000 Per Capita GDP (PPP) } \\
\hline ESTIMATION METHOD: 2 SLS & Model 1 & Model 2 & Model 3 & Model 4 & Model 5 & Model 6 \\
\hline Institutional Quality (Property Rights) & $\begin{array}{l}0.463 * * * \\
(10.57)\end{array}$ & $\begin{array}{l}0.430 * * * \\
(9.02)\end{array}$ & $\begin{array}{l}0.504 * * * \\
(6.53)\end{array}$ & & & \\
\hline Institutional Quality (Rule of Law) & & & & $\begin{array}{l}1.082 * * * \\
(9.12)\end{array}$ & $\begin{array}{l}1.019 * * * \\
(8.01)\end{array}$ & $\begin{array}{l}1.296 * * * \\
(9.44)\end{array}$ \\
\hline Log Agricultural Transition Date & $\begin{array}{l}0.192 * * \\
(2.16)\end{array}$ & $\begin{array}{l}0.175^{* *} \\
(2.12)\end{array}$ & $\begin{array}{l}0.200 * * \\
(1.96)\end{array}$ & $\begin{array}{l}0.147 * * \\
(2.01)\end{array}$ & $\begin{array}{l}0.139 * \\
(1.92)\end{array}$ & $\begin{array}{l}0.247 * * \\
(2.21)\end{array}$ \\
\hline Shelf Area / Surface Area & $\begin{array}{l}0.0656^{* * * *} \\
(2.79)\end{array}$ & $\begin{array}{l}0.0684 * * * \\
(2.88)\end{array}$ & $\begin{array}{l}0.0633 * * * \\
(3.03)\end{array}$ & $\begin{array}{l}0.0293 \\
(1.19)\end{array}$ & $\begin{array}{l}0.0334 \\
(1.44)\end{array}$ & $\begin{array}{l}-0.122 \\
(-1.38)\end{array}$ \\
\hline Malaria Intensity & $\begin{array}{l}-0.051 * * * \\
(-5.96)\end{array}$ & $\begin{array}{l}-0.044 * * * \\
(-4.57)\end{array}$ & $\begin{array}{l}-0.0226 * \\
(-1.76)\end{array}$ & $\begin{array}{l}-0.032 * * * \\
(-4.14)\end{array}$ & $\begin{array}{l}-0.035^{* * *} \\
(-4.71)\end{array}$ & $\begin{array}{l}-0.00895 \\
(-0.89)\end{array}$ \\
\hline Oil Producers & $\begin{array}{l}0.300 * * \\
(2.04)\end{array}$ & & & $\begin{array}{l}0.317 * * \\
(2.34)\end{array}$ & & \\
\hline Ethnic Fractionalization & & $\begin{array}{l}-0.550 * \\
(-1.84)\end{array}$ & & & $\begin{array}{l}-0.163 \\
(-0.58)\end{array}$ & \\
\hline Latin America Dummy & & & $\begin{array}{l}0.400 * \\
(1.69)\end{array}$ & & & $\begin{array}{l}0.712 * * * \\
(3.14)\end{array}$ \\
\hline Africa Dummy & & & $\begin{array}{l}-0.460 \\
(-1.63)\end{array}$ & & & $\begin{array}{l}-0.160 \\
(-0.73)\end{array}$ \\
\hline Constant & $\begin{array}{l}4.445^{* * * *} \\
(5.39)\end{array}$ & $\begin{array}{l}5.030 * * * \\
(6.39)\end{array}$ & $\begin{array}{l}4.154 * * * \\
(3.248)\end{array}$ & $\begin{array}{l}7.292 * * * \\
(11.61)\end{array}$ & $\begin{array}{l}7.498 * * * \\
(11.60)\end{array}$ & $\begin{array}{l}6.433 * * * \\
(6.51)\end{array}$ \\
\hline Cragg-Donald F statistic & 55.15 & 56.38 & 22.93 & 32.23 & 31.83 & 38.17 \\
\hline Stock-Yogo Critical Values for CD Stat. & $(16.38)$ & $(16.38)$ & $(16.38)$ & $(16.38)$ & $(16.38)$ & $(16.38)$ \\
\hline Anderson LR statistic & 46.62 & 47.46 & 22.10 & 30.17 & 29.84 & 35.21 \\
\hline Hansen J statistic & 0.0000 & 0.0000 & 0.0000 & 0.0000 & 0.0000 & 0.0000 \\
\hline Endogeneity Test (p-values) & 0.1828 & 0.3603 & 0.1356 & 0.0689 & 0.1785 & 0.0000 \\
\hline Root MSE & 0.58 & 0.57 & 0.56 & 0.56 & 0.55 & 0.62 \\
\hline R-Squared & 0.75 & 0.77 & 0.77 & 0.78 & 0.78 & 0.72 \\
\hline Observations & 107 & 107 & 109 & 140 & 140 & 134 \\
\hline Instruments & & & Latitude & & & $\begin{array}{l}\text { Climate } \\
\text { Zone } \\
\end{array}$ \\
\hline
\end{tabular}

The figures in parentheses are robust $t$-statistics; $* * * \mathrm{p}<0.01,{ }^{* *} \mathrm{p}<0.05, * \mathrm{p}<0.1$

In summary, the finding that the agricultural transition date is positively correlated with current per capita incomes seems to be robust. 


\section{6) A Reversal of Fortune?}

As mentioned earlier, Acemoglu et al. (2002) have suggested that countries that were subject to European colonisation after 1500 have experienced a "reversal of fortune", with the poorer ones tending to have higher per capita incomes today than those that were rich in 1500 . They argue that the quality of institutions established in the colonies reflected not just the disease environment, as reflected in settlers' mortality (as they had previously argued in Acemoglu et al., 2001), but also the tendency to establish "extractive institutions" in areas of high population density such as MesoAmerica. This argument suggests that any effect of the agricultural transition date on per capita income in these countries that existed in 1500 has been erased by what happened in colonial times. Consequently the relationship between the agricultural transition date and current per capita incomes should be much weaker for excolonies, or at least for those that were colonised many centuries ago.

To test this hypothesis we consider whether the AT coefficient varies across the sample. In results that are not shown, we found that there was no significant difference between ex-colonies and the rest. There is, however, a significant difference between early ex-colonies (those colonised before 1850) and the rest of the sample, as shown in Table 9. The regressions in Table 9 are Models 1 and 2 of Table 7, with the addition of a dummy that is equal to one for a country that was colonised before 1850, and zero otherwise, and this dummy multiplied by AT. The 
F-statistic shows that, in both cases (using either property rights or the rule of law as the measure of institutional quality), the null hypothesis that these two additional variables have zero coefficients can be rejected at the 0.05 level. Moreover in both cases, the estimated coefficient of AT for early colonies is only about 0.1 , much smaller than in the rest of the sample (although not actually negative as the "reversal of fortune" hypothesis suggests).

Table 9: Testing for Differences in Early Colonies

\begin{tabular}{lll}
\hline \multicolumn{2}{c}{ Dependent Variable: 2000 GDP per capita } \\
\hline ESTIMATION METHOD: 2SLS & Model 1 & Model 2 \\
\hline Institutional Quality (Property Rights) & $0.483^{* * *}$ & \\
& $(7.22)$ & $1.112^{* * * *}$ \\
Institutional Quality (Rule of Law) & & $(8.13)$ \\
& & $0.384^{* * *}$ \\
Log Agricultural Transition Date (AT) & $0.488^{* * *}$ & $(3.18)$ \\
& $(2.69)$ & -0.276 \\
EC Dummy * AT & -0.372 & $(-1.48)$ \\
& $(-1.40)$ & -0.00191 \\
Shelf Area & 0.0293 & $(-0.07)$ \\
& $(1.18)$ & $-0.0247 * * *$ \\
Fatal Malaria Risk & $-0.0391 * * *$ & $(-2.80)$ \\
& $(-3.80)$ & $2.592^{*}$ \\
Pre-1850 Colonisation Dummy (EC) & 3.396 & $(1.71)$ \\
& $(1.58)$ & $5.257 * * *$ \\
Constant & 1.777 & $(5.00)$ \\
& $(1.11)$ & \\
Endogeneity Test & & 0.0906 \\
Cragg-Donald F-Statistic & 0.2109 & 26.73 \\
Stock-Yogo Critical Values for CD Statistic & 36.27 & $(16.38)$ \\
Anderson LR-Statistic & $(16.38)$ & 25.660 \\
Hansen J-Statistic & 33.162 & 0.000 \\
F-test (EC \& EC*AT coeffs=0) ( $p$-value) & 0.0000 & 0.0143 \\
Root MSE & 0.0373 & 0.56 \\
R-Squared & 0.57 & 0.78 \\
Observations & 0.76 & 143 \\
\hline
\end{tabular}

Robust $t$-statistics in parentheses; *** $\mathrm{p}<0.01, * * \mathrm{p}<0.05,{ }^{*} \mathrm{p}<0.1$ 
If the agricultural transition date can be taken as an index of development in precolonial times, then the reversal of fortune hypothesis suggests that institutional quality should be negatively correlated with it, at least for the early colonies. Table 10 shows regressions for institutional quality in the entire sample, but allowing the AT coefficient to vary first between ex-colonies and the rest (Models 3 and 4), and then between early colonies and the rest (Models 5 and 6). In neither case is there evidence of a significant difference in the AT coefficient across the sample. There tends to be a negative relationship between AT and institutional quality, but not a statistically significant one, and what stands out is the strong relationship between institutional quality and latitude. 
Table 10: Determinants of Institutional Quality

\begin{tabular}{|c|c|c|c|c|c|c|}
\hline & \multicolumn{6}{|c|}{ OLS ESTIMATES } \\
\hline & Model 1 & Model 3 & Model 3 & Model 4 & Model 5 & Model 6 \\
\hline Dependent Variables: & Property R. & Rule of Law & Property R. & Rule of Law & Property R. & Rule of Law \\
\hline $\begin{array}{l}\text { Log Agricultural Transition Date } \\
\text { (AT) }\end{array}$ & $\begin{array}{l}-0.316 \\
(-1.07)\end{array}$ & $\begin{array}{l}-0.186 \\
(-1.38)\end{array}$ & $\begin{array}{l}-0.624^{*} \\
(-1.82)\end{array}$ & $\begin{array}{l}-0.235 \\
(-1.45)\end{array}$ & $\begin{array}{l}0.0767 \\
(0.18)\end{array}$ & $\begin{array}{l}-0.223 \\
(-1.31)\end{array}$ \\
\hline AC Dummy * AT & & & $\begin{array}{l}0.128 \\
(1.58)\end{array}$ & $\begin{array}{l}0.0437 \\
(1.43)\end{array}$ & & \\
\hline EC Dummy * AT & & & & & $\begin{array}{l}-0.959 * \\
(-1.68)\end{array}$ & $\begin{array}{l}0.115 \\
(0.44)\end{array}$ \\
\hline Shelf Area & $\begin{array}{l}0.141 \\
(1.55)\end{array}$ & $\begin{array}{l}0.147^{*} \\
(1.74)\end{array}$ & $\begin{array}{l}0.127 \\
(1.28)\end{array}$ & $\begin{array}{l}0.147^{*} \\
(1.69)\end{array}$ & $\begin{array}{l}0.0747 \\
(0.73)\end{array}$ & $\begin{array}{l}0.154 * \\
(1.78)\end{array}$ \\
\hline Latitude & $\begin{array}{l}0.0725^{* * *} \\
(6.84)\end{array}$ & $\begin{array}{l}0.0304 * * * \\
(5.78)\end{array}$ & $\begin{array}{l}0.0708^{* * * *} \\
(4.66)\end{array}$ & $\begin{array}{l}0.0329 * * * \\
(4.18)\end{array}$ & $\begin{array}{l}0.0640 * * * \\
(5.36)\end{array}$ & $\begin{array}{l}0.0317 * * * \\
(5.24)\end{array}$ \\
\hline Fatal Malaria Risk & $\begin{array}{l}-0.0107 \\
(-0.69)\end{array}$ & $\begin{array}{l}-0.0111 \\
(-1.55)\end{array}$ & $\begin{array}{l}-0.00690 \\
(-0.44)\end{array}$ & $\begin{array}{l}-0.00944 \\
(-1.37)\end{array}$ & $\begin{array}{l}-0.0159 \\
(-0.78)\end{array}$ & $\begin{array}{l}-0.00973 \\
(-1.20)\end{array}$ \\
\hline Ex-Colony Dummy (AC) & & & $\begin{array}{l}-1.297 * \\
(-1.70)\end{array}$ & $\begin{array}{l}-0.258 \\
(-0.70)\end{array}$ & & \\
\hline Early Colony Dummy (EC) & & & & & $\begin{array}{l}7.507 \\
(1.58)\end{array}$ & $\begin{array}{l}-0.862 \\
(-0.40)\end{array}$ \\
\hline Constant & $\begin{array}{l}6.501 * * * \\
(2.72)\end{array}$ & $\begin{array}{l}0.634 \\
(0.59)\end{array}$ & $\begin{array}{l}9.202 * * * \\
(2.97)\end{array}$ & $\begin{array}{l}0.900 \\
(0.59)\end{array}$ & $\begin{array}{l}3.556 \\
(0.99)\end{array}$ & $\begin{array}{l}0.887 \\
(0.66)\end{array}$ \\
\hline F-test (AC \& AC*AT) (p-values) & & & 0.2333 & 0.7956 & & \\
\hline F-test (EC \& EC*AT) (p-values) & & & & & 0.0987 & 0.8074 \\
\hline Observations & 111 & 153 & 111 & 153 & 111 & 153 \\
\hline Root MSE & 1.45 & 0.85 & 1.44 & 0.85 & 1.43 & 0.85 \\
\hline R-squared & 0.45 & 0.31 & 0.45 & 0.32 & 0.47 & 0.31 \\
\hline
\end{tabular}

Robust $\mathrm{t}$ statistics in parentheses: $* \mathrm{p}<0.01, * * \mathrm{p}<0.05, * \mathrm{p}<0.1$; the null for the F-tests is that both coefficients are zero 


\section{7) Conclusions}

We have tested the Diamond-Olsson-Hibbs hypothesis that prehistoric biogeography determined the date of the transition to agriculture and thereby still influences per capita incomes today, using the rich data set on the transition of Putterman and Trainor (2006). We confirm both elements of the hypothesis: the correlation between prehistoric biogeography and the transition to agriculture, and between the timing of the transition to agriculture and current per capita incomes. Our results are robust to alternative measures of institutional quality and of geographical factors, and to the inclusion of regional and other dummies. There is a significantly weaker correlation between the timing of the agricultural transition and per capita income in early colonies, which is consistent with the Acemoglu et al. (2002) argument that the colonisation process led to faster development in the poorer regions, although we do not find evidence of an actual "reversal of fortune". An early transition to agriculture is not associated with better institutions, which are strongly correlated with latitude but little else. 


\section{Data Appendix}

\begin{tabular}{|c|c|}
\hline Variable & Source \\
\hline Cumulative Years Since the & Putterman and Trainor (2006) \\
\hline Transition to Agriculture & www.econ.brown.edu/fac/Louis_Putterman \\
\hline Prehistoric Bio-geographical & Olsson and Hibbs (2005) \\
\hline Conditions & $\underline{\text { www.douglas-hibbs.com }}$ \\
\hline Rule of Law & $\begin{array}{l}\text { Kaufman et al. (2005) } \\
\text { www.info.worldbank.org.governance/wgi/index.asp }\end{array}$ \\
\hline Property Rights & $\begin{array}{l}\text { Gwartney and Lawson (2006) } \\
\text { www.freetheworld.com }\end{array}$ \\
\hline $\begin{array}{l}\text { Latitude, Population Share Speaking } \\
\text { European Languages, Fatal Malaria } \\
\text { Risk. }\end{array}$ & $\begin{array}{l}\text { Sachs (2003) } \\
\text { http://www.earth.columbia.edu/articles/view/1040 }\end{array}$ \\
\hline Continental Shelf Area & $\begin{array}{l}\text { Pruett and Cimino (2000) } \\
\text { www.unep.org/GEO/geo3/ }\end{array}$ \\
\hline Ethnic Fractionalization & $\begin{array}{l}\text { Fearon and Laitin (2003) } \\
\text { www.stanford.edu/ jfearon/ }\end{array}$ \\
\hline Oil Producers & $\begin{array}{l}\text { International Energy Agency } \\
\text { www.esds.mcc.ac.uk/wds_iea/ }\end{array}$ \\
\hline Years of Colonisation & $\begin{array}{l}\text { World Statesmen.org } \\
\text { www.worldstatesmen.org }\end{array}$ \\
\hline $\begin{array}{l}\text { GDP per Capita (2000) (PPP } \\
\text { adjusted) }\end{array}$ & $\begin{array}{l}\text { World Bank. (World Development Indicators) } \\
\underline{\text { www.esds.mcc.ac.uk/wds_wb/ }}\end{array}$ \\
\hline Trade at Current Prices & $\begin{array}{l}\text { Heston and Summers (2006) (Penn World Table 6.2) } \\
\text { www.pwt.econ.upenn.edu }\end{array}$ \\
\hline Frankel and Romer Trade Shares & Frankel and Romer (1999). Appendix to the Paper. \\
\hline $\begin{array}{l}\text { Average Temperature, Frost Days } \\
\text { and Wet Days }\end{array}$ & $\begin{array}{l}\text { Mitchel et al. (2003). } \\
\text { www.cru.uea.ac.uk/cru/data/hrg }\end{array}$ \\
\hline
\end{tabular}




\section{References}

Acemoglu, Daron, Simon Johnson, and James A. Robinson, "The Colonial Origins of Comparative Development: An Empirical Investigation," American Economic Review, December 2001, 91 (5), 1369-1401.

, and _, "Reversal of Fortune: Geography And Institutions In The Making of The Modern World Income Distribution," The Quarterly Journal of Economics, November 2002, 117 (4), 1231- 1294.

Diamond, J., "Guns, Germs and Steel: The Fates of Human Societies.," Norton, 1997

Easterly, William and Ross Levine, "Africa's Growth Tragedy: Policies and Ethnic Divisions," Quarterly Journal of Economics, November 1997, 112(4), 1203-50

Fearon, James D. and David D. Laitin, "Ethnicity, Insurgency, and Civil War," The American Political Science Review, 2003, 97 (1), 75-90.

Frankel, Jeffrey A. and David Romer, "Does Trade Cause Growth?" American Economic Review, June 1999, 89 (3), 379-399.

Gwartney, James and Robert Lawson, "Economic Freedom of the World: 2007 Annual Report," The Fraser Institute, 2006.

Hall, Robert E. and Charles I. Jones, "Why Do Some Countries Produce So Much More Output Per Worker Than Others?," The Quarterly Journal of Economics, February 1999, 114 (1), 83-116.

Heston, Robert, and Alan Summers, "Penn World Table version 6.2," Center for International Comparisons of Production, Income and Prices, 2006.

Hudson and Taylor, "World Handbook of Political and Social Indicators," New Haven, Yale University Press 1972.

International Energy Agency (IEA), “Oil Information 2006," ESDS International, (Mimas) University of Manchester

Kaufmann, Daniel, Aart Kraay, and Massimo Mastruzzi, "Governance Matters IV: Governance Indicators for 1996-2004," Policy Research Working Paper Series 3630, the World Bank June 2005.

Kizsewski, Anthony, Pia Malaney, Andrew Mellinger, Andrew Spielman, Sonia Ehrlich Sachs, and Jeffrey D. Sachs, "A Global Index of the Stability of Malaria Transmission Based on the Intrinsic Properties of Anopheline 
Mosquito Vectors," American Journal of Tropical Medicine and Hygiene 2004, 70(5): 486-498.

Mitchell, M., T. D., Carter T.R. Jones P.D. Hulme M. “A comprehensive set of high-resolution grids of monthly climate for Europe and the globe: the observed record (1901-2000) and 16 scenarios (2001-2100)," Journal of Climate, 2003

Olsson O. and Douglas Jr. Hibbs, "Biogeography and long-run economic development," European Economic Review, May 2005, 49 (4), 909-938.

Pruett, L. and C. Cimino, "Global Maritime Boundaries Database (GMBD)," GEO.3, UNEP, 2000.

Putterman, L. and C.A. Trainor, "Agricultural Transition Year Country Data Set," Brown University, 2006.

Rodrik, Dani, Arvind Subramanian and Francesco Trebbi, "Institutions Rule: The Primacy of Institutions over Integration and Geography in Economic Development," Journal of Economic Growth, June 2004, vol. 9(2) pg 131-165

Sachs, Jeffrey D., "Institutions Don't Rule: Direct Effects of Geography on Per Capita Income," NBER Working Paper 9490, February 2003, National Bureau of Economic Research Inc.

Shea, John, "Instrument Relevance in Multivariate Linear Models: A Simple Measure," NBER Technical Working Papers 0193, National Bureau of Economic Research, Inc March 1996.

Stock, James H. and Motohiro Yogo, "Testing for Weak Instruments in ho Rothenberg. Cambridge: Cambridge University Press, 2005, pp.80-108

Stock, James H, Jonathan H Wright, and Motohiro Yogo, "A Survey of Weak Instruments and Weak Identification in Generalized Method of Moments," Journal of Business \& Economic Statistics, October 2002, 20 (4), 518-29. 